This is an author generated post-print of the article:

Coelho, S., Russo, M., Oliveira, R., Monteiro, A., Lopes, M., Borrego, C. Sustainable energy action plans at city level: A Portuguese experience and perception. Journal of Cleaner Production 176, 1223-1230.

The final publication is available on http://dx.doi.org/10.1016/j.jclepro.2017.11.247 


\title{
SUSTAINABLE ENERGY ACTION PLANS AT CITY LEVEL: A PORTUGUESE EXPERIENCE AND PERCEPTION
}

Silvia Coelho, Michael Russo, Ruben Oliveira, Alexandra Monteiro*, Myriam Lopes, Carlos Borrego CESAM \& Department of Environment and Planning, University of Aveiro, 3810-193 Aveiro, Portugal

*Corresponding author: alexandra.monteiro@ua.pt | Phone: +351 234370220 | Fax: +351 234370309

\begin{abstract}
In order to achieve the targets underlined in the European Strategy for climate change and energy efficiency, the so called 20-20-20 package, the European Commission launched the Covenant of Mayors to endorse and support the efforts deployed by local authorities in the implementation of sustainable energy plans, and at the same time contribute to greenhouse gases emissions mitigation. This paper explores how the Covenant of Mayors (CoM) has been adopted in Portugal, and which type of measures are being defined and implemented by the municipalities. For that, all Sustainable Energy Action Plan (SEAP) submitted by Portuguese municipalities (124) have been examined, for which a detailed analysis was performed, including the Baseline Emission Inventory (70, i.e., around 50\%). The municipalities that submitted SEAP cover $60 \%$ of the total population of the country because the main urban centres are a part of the $30 \%$ that have signed the CoM. Most common measures are related with changes on behaviour and infrastructure related to energy (such as renewable energies, energy efficiency in buildings, public lighting, etc.), waste and transport (for example optimization of: transport infrastructures, used vehicles and road operations). Public lighting is one of the energy measures present in all submitted SEAP, which plays a key role in energy consumption, reaching values of upwards of $12 \%$, particularly in coastal areas due to higher population density and urban residential areas. Besides all efforts there is still a long way to go in terms of energy consumption reduction at local level.
\end{abstract}

Key words: energy; $\mathrm{CO}_{2}$ emissions; Covenant of Mayors; public lighting; Portugal

\section{INTRODUCTION}

In recent years, energy policy has gained top priority on international agendas and is, presently, a major concern in the European Union (EU) (Helm, 2014). The EU energy and climate package has set goals to reduce greenhouse gas (GHG) emissions by $20 \%$ by 2020 . To meet these goals, national governments should take energy cost-saving and energy efficiency measures, as well as increase renewable energy production. These measures, according to the Renewable Energy Directive (Directive 2009/28/EC), should be implemented at all territorial levels, with local 
emphasis. This is evidenced by a recent surge in reports, from major international organisations, which consider cities as both a means and a target for climate actions (Kona et al, 2016). Under this priority action, the Covenant of Mayors (CoM) initiative was launched in January 2008, aiming to exchange and apply best practices between European cities and towns (EC, 2014). Specifically, the main goal is to significantly improve energy efficiency in the urban environment, where local policy decisions and initiatives are important. The Covenant of Mayors initiative invites cities, towns or regions (called "signatories") to voluntarily commit to a reduction of their GHG emissions by at least $20 \%$ by the year 2020 . The municipalities that have adhered to the Covenant have signed a declaration stating that they pledge to exceed these objectives by implementing a Sustainable Energy Action Plan (SEAP). The purpose of a SEAP is to define the actions that each local region must carry out in order to exceed the goals set by the EU by 2020, and to achieve this, cross-cutting involvement by the municipality is needed.

This initiative had the objective of sparking and supporting the efforts of municipal administrations, a basic unit of the public administration, in the process of actualizing energy and climate change policies (Delponte et al., 2017; Croci et al., 2017). Several research studies have illustrated the importance of this initiative. According to Kern and Bulkeley (2009), recent developments show that the relations between city pioneers and the EU have become tighter, and the cities' strategy of cooperating directly with the EU has reached a new phase of development. As stated by Radulovic et al. (2011), the Mayors have the opportunity to make an impact on climate change initiatives by starting a new energy policy. Other studies, focusing on local policies, have examined motivations, which lead local governments to join city-networks to promote climate change action (Zahran et al., 2008; Krause, 2011; Sharp et al., 2011; Wang, 2012). Others have compared the actions of a group of major world cities or a group of cities of a particular country. Yalçın and Lefèvre (2012) analyse the first generation of voluntary and partnership-based climate action plans in France. Hoff and Strobel (2013) look at how Danish municipalities have tackled the issue of climate change. Study groups have undertaken comparative research that considers a more geographically diverse range (Castán et al., 2012; Romero-Lankao, 2012; Reckien et al., 2014). During the last several years, CoM has therefore been assuming an increasing role in achieving the targets of the Kyoto Protocol and, now, of the Paris Agreement. However, the success of this initiative and its ongoing evolution do not remove the complexity and problems of the SEAP implementation.

The high number of signatories does not necessarily imply that the goals of CoM will be achieved. Commitment is required by the local communities, along with the ability to find and exploit available instruments to finance the required improvements. More importantly, the CoM is a citizen-based initiative, as it is difficult to succeed in the aforementioned GHG emissions reductions without citizens taking decisive action. Thus, the success of this program will depend on the adopted measures by local governments, and consequently, public acceptance and 
participation. Portugal, for its geopolitical position in the Mediterranean area, represents a natural bridge between the countries of North Africa and those of Northern Europe, positioning itself to become a hub for the development of sustainable energies in the Mediterranean area. Therefore, the development of this initiative is fundamental in regional policies, and could be an important example to follow by other regions.

In the above context, this paper aims to provide answers to the following questions mainly:

- Which type of measures are being defined and implemented by the Portuguese municipalities?

- Which are the most relevant sectors, subsectors, actions and policy levels to mitigate climate change in Portuguese municipalities?

In addition, this review will be particularly relevant, to our knowledge, in guiding future cities on designing a strategy for emission reduction, and take actions for $\mathrm{CO}_{2}$ emission reductions. At the same time, identifying different priority areas to be developed in order to obtain the expected GHG reduction, promoting the knowledge transfer among cities and consequently improving innovation in city policies to reduce $\mathrm{CO}_{2}$ emissions. This collection of experiments emerged as a way of obtaining potential knowledge, practices, networks and significant examples of local and regional sustainability governance.

The present work is organized as follows: Section 2 provides an overview of the Covenant of Mayors initiative and the associated sustainable energy action plan. The application and implementation of these plans over Portugal municipalities is explored in Session 3. A special focus on the public lighting sector over Portugal is performed in Section 4, and finally conclusions are drawn in Section 5.

\section{LITERATURE REVIEW ON SEAP- CONVENANT OF MAYORS}

To meet the $\mathrm{CO}_{2}$ reduction targets established in the CoM, three steps are needed by local authorities (Figure 1). Within the year following the adhesion to the initiative, local authorities have to define a minimum $\mathrm{CO}_{2}$ emission reduction by 2020 and approve and submit the SEAP. The SEAP is the key document through which the signatory presents its objectives and outlines a comprehensive set of actions that local authorities plan to undertake in order to reach their target. The SEAP also includes a Baseline Emission Inventory (BEI), which provides an analysis of the current situation in terms of energy consumption, GHG emissions. Signatories are requested to monitor and report on their SEAP implementation every second year (Kona et al., 2016). 


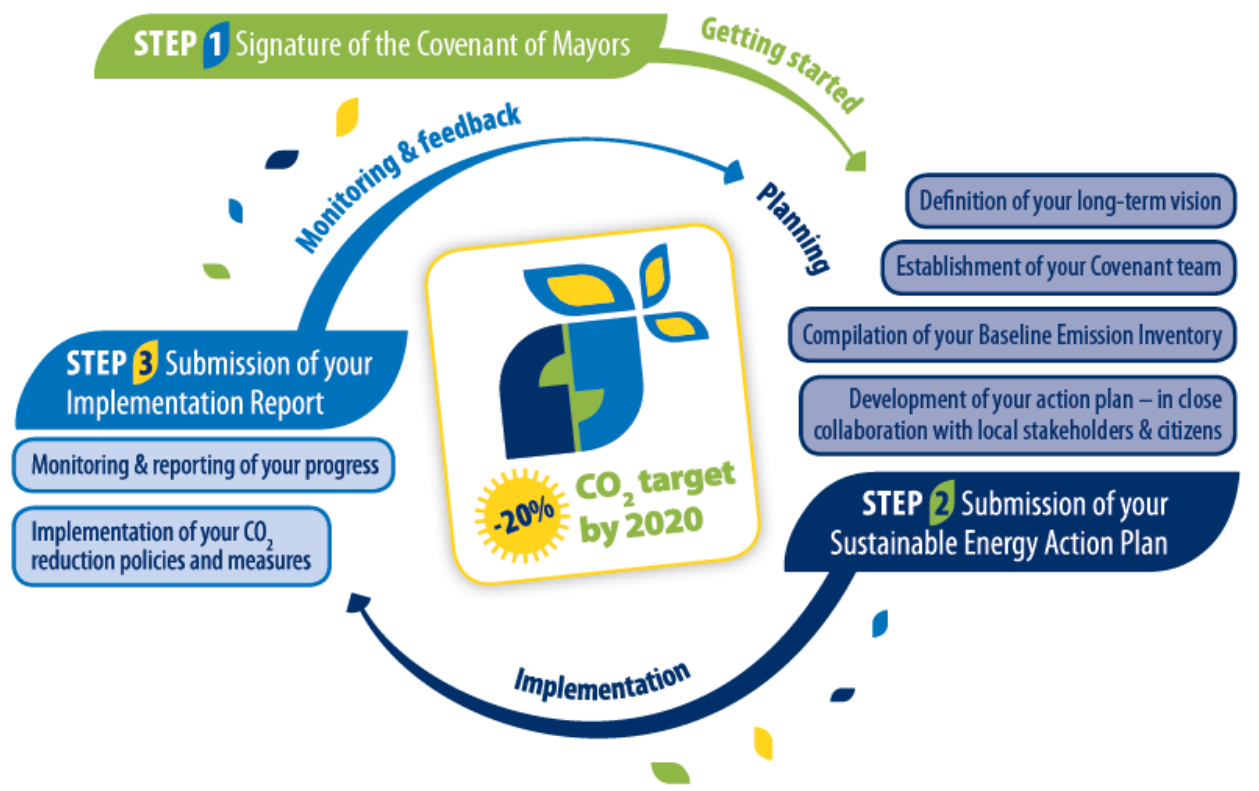

Figure 1. Covenant of Mayors step-by-step (EC, 2014).

The CoM has succeeded in mobilising a great number of local and regional authorities, not only in Europe but also in other parts of the world (EC, 2017), currently numbering more than 7300 signatories (Figure 2) and more than 5500 SEAPs already developed.

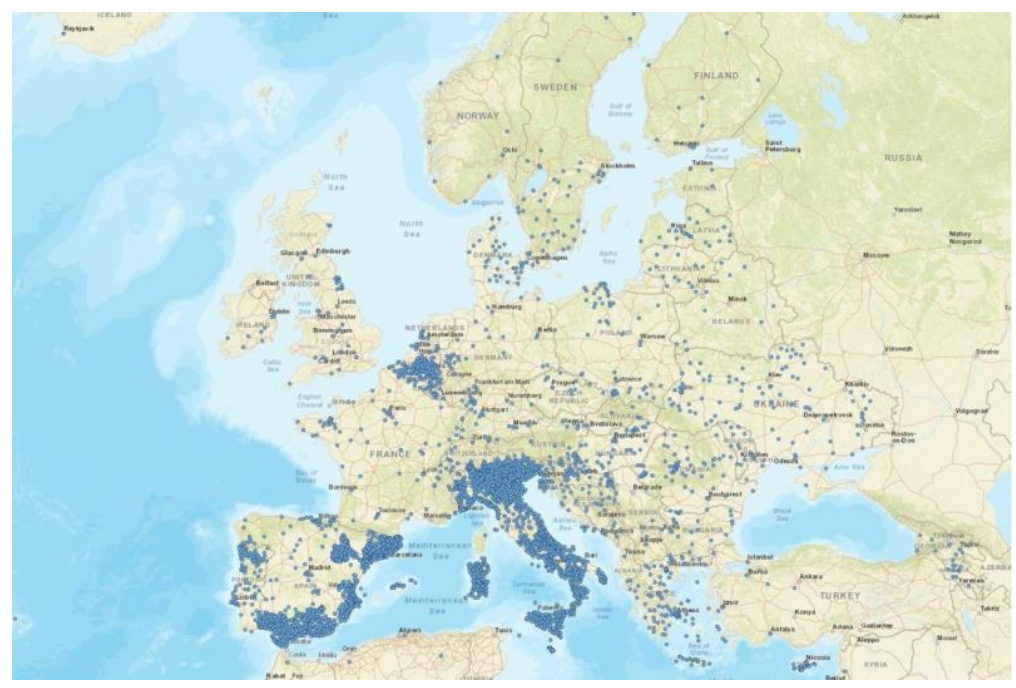

Figure 2. Covenant of Mayors signatories map (Kona et al. 2016).

The progression of the CoM initiative and the main issues related to the development of SEAPs have been analysed in several studies. Cerutti et al. (2013) and Kona et al. (2015) evaluated the evolution of the CoM key figures in a five- and six-year outlook, respectively. Again Melica et al. (2014) presented the evaluation of the CoM after 6 years, but including the expansion of the scheme for Former Soviet Union Countries and North Africa. Amorim (2014) explored the 
content of several SEAPs for 14 countries in Europe, providing an overview of existing methodologies for the development and implementation of SEAPs by municipalities. Kona et al. (2016) studied the GHG emissions achievements and projections for the first 315 SEAPs' implementation reports, while Iancu et al. (2015) collected the emission inventories at municipal level directly computed by the signatories of CoM.

Following this perspective, many studies have analysed the experience of the signatories after joining the CoM movement and/or the developing of the correspondent SEAPs. The experience of these signatories is interesting for other municipalities that intend to join CoM or develop their SEAP, helping to identify the key aspects and issues that should to be considered. Among these studies may be pointed out that by Nuss-Girona et al. (2016) showing the development process of a SEAP in a typical, medium-sized Mediterranean city, Girona, highlighting its strengths and discussing the greatest challenges faced. Following this line, Christoforidis et al. (2013) analysed the public perception issues and barriers in signing CoM, in municipalities of Greece. Doukas et al. (2012) performed the assessment of the energy sustainability of rural communities, applied in some mountainous and agricultural communities and islands in Europe, using Principal Component Analysis. Similarly, Marinakis et al. (2015, 2017) assessed the local communities' needs and priorities to identify the key parameters that must be taken into account during the development of SEAPs, for rural municipalities from Austria, Croatia, Greece and Portugal. Heidrich et al. (2013) evaluated the adaptation/mitigation action plans of 30 urban areas of United Kingdom and Rivas et al. (2015) made a detailed analysis of SEAP reports for 25 cities from different EU Member States. Oliver-Solá et al. (2013) studied the energy consumption and GHG emission of municipal service facilities in Barcelona. Magni and Maragno (2014) defined a preliminary study for the local action plan for climate in Rovigo municipalities. Likewise, Lombardi et al. (2014) analysed the methodologies used for the elaboration of SEAPs in Foggia municipalities and Famoso et al. (2015) analysed the CoM initiative in Sicily. Pablo-Romero et al. (2015a, 2015b) described which factors influence the most the decision of Spanish local authorities in joining the CoM initiative and Pablo-Romero et al. (2016) analysed whether joining the CoM and developing the corresponding SEAP, are reducing the consumption of electricity and its emissions in the municipalities of Andalusia. Damsø et al. (2016) assessed the relevance of local climate action planning in mitigation global climate change for almost CoM signatories in Denmark municipalities. Matak et al. (2016) presented indicators that are used for the calculation of BEI and compares the two different types of the joining the CoM initiative, individual or joint approach, for Korcula municipalities. Finally, Delponte et al. (2017) illustrated the SEAP monitoring strategy and implemented the case of Genoa for reflections based on field experience.

The development of SEAPs is a complex work due to different aspects (e.g., social, technological) and different sectors (e.g., transport, residential) that can be considered. Because of this, some 
signatories developed a set of methodologies and tools, which have been implemented to facilitate the development of their SEAPs. These tools have been analysed by authors, such as Dall'O et al. (2012), that describes a new methodology to evaluate the potential energy savings of retrofitting building stocks, in Milan municipalities, considering the technological and economic constraints of the implementation of feasible energy efficiency measures. Likewise, Zanni et al. (2015) developed a tool, applicable to school buildings in Castelfranco Veneto municipalities, which identified the type of building and construction technology to estimate the immediate reduction of consumption and emitted $\mathrm{CO}_{2}$. Kyriakarakos et al. (2014) presented the design and implementation of fuzzy cognitive maps as a decision making support toolkit, for planning local renewable energy sources in Crete Island. Dall'O et al. (2013) applied a multi-criteria analysis based on the ELECTRE III method, to support public administration and local authorities of Lombardy region in developing SEAPs, while Bjelic and Ciric (2013) tested the simulation tool HOMER, for the configuration plan of the municipal microgrids in Serbia. Marinakis et al. (2015, 2017) developed an online interactive support framework, for the elaboration of SEAPs of rural communities from Austria, Croatia, Greece and Portugal. In addition, Marinakis et al. (2016) presented a decision support model for the elaboration of scenarios of energy consumption and $\mathrm{CO}_{2}$ emissions at local and regional level, applied in Greek municipalities.

Despite all these analysis, there is little information about Portuguese participation in the CoM initiative and subsequent implementation of SEAPs. However, Portugal is one of the most committed countries in this initiative, with approximately $59 \%$ of the total population of the country involved in the CoM. Only five European countries have higher or equal proportion of population involved in the CoM, they are Belgium (100\%), Italy (71\%), Spain (67\%), Denmark $(61 \%)$ and Greece (59\%) (EC, 2017). Following this, this paper aims to contribute to the scientific literature by analysing the Portuguese participation in the CoM initiative, understanding which type of measures are being defined in the SEAPs, and which are the most relevant ones.

\section{METHOD: SEAP COMPILATION AND ANALYSIS}

The SEAP is a key document that shows how the signatories will reach their commitment by 2020, using the BEI results to identify the best fields of action and opportunities to achieve the proposed objectives. It also sets out concrete measures of reduction, together with deadlines and signed responsibilities, which translate the long-term strategy into action (Kona et al, 2016).

Currently, the number of CoM signatories in Portugal total 140, covering 6154985 inhabitants (59\% of the total population of the country), of which 124 (89\%) have already submitted a SEAP, but only 70 (50\%) present concrete data regarding BEI (EC, 2017). The presented analysis will be focused on this $50 \%$ fraction (70 SEAPs).

Information about the type of commitment of each municipality in Continental Portugal is shown in Figure 3. 


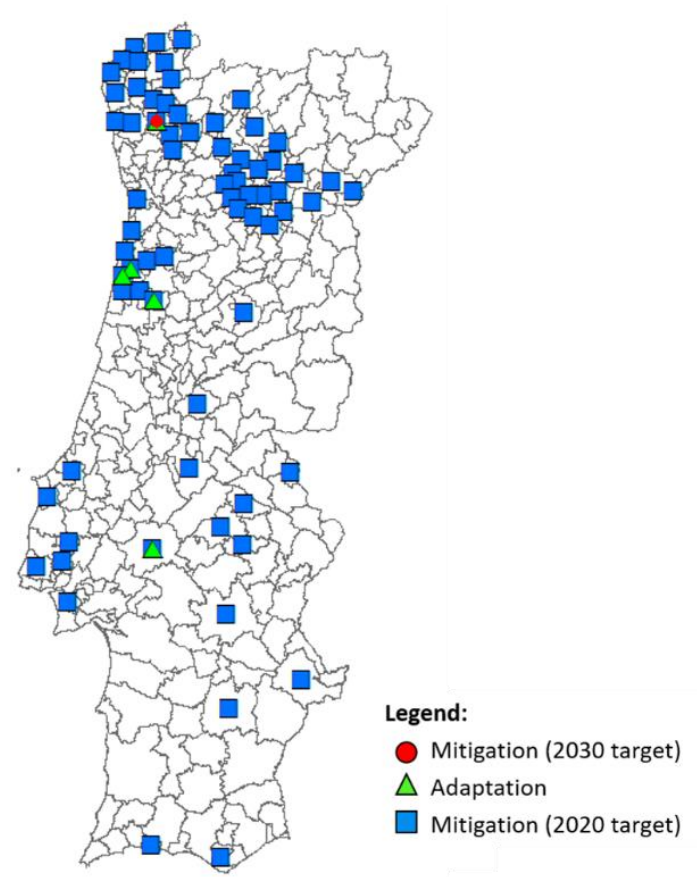

Figure 3. Type of commitment assigned to each of municipality in Continental Portugal.

All 70 municipalities with a SEAP and BEI with detailed data signed the first CoM focused on mitigation with at least $20 \% \mathrm{CO}_{2}$ emission reduction target by 2020 . Five of which also signed Mayors Adapt and are already working on defining adaptation measures. Only one municipality, Braga, signed the CoM for Energy and Climate, with the commitment of reducing at least $40 \%$ of $\mathrm{CO}_{2}$ emissions by 2030. The municipalities in white, which represent more than $65 \%$ of the total, are the ones without data in the SEAP or that have not signed the CoM. Nevertheless, it should be noticed that the major urban areas existent in Portugal are covered, Lisbon being the exception because it has signed the CoM but has no detailed information regarding the BEI. In order to help the signatories developing the SEAP, a guidebook entitled "How to develop a Sustainable Energy Action Plan" (Bertoldi et al., 2010) was created. This guidebook recommended using 1990 as the BEI year, which is the reference year for the reduction target. However, signatories can choose the closest following year for which data can be collected, resulting in different BEI years been chosen by the signatories (Kona et al., 2016). In fact, the analysis of the SEAPs reveal that none of the 70 municipalities chose 1990 as a BEI year, most of them decided to use 2008 (64\%), 2009 (13\%), 2010 (17\%), or others recent years (6\%). Using 2008 instead of 1990 at EU level could mean a more ambitious $20 \%$ reduction target by 2020 , because of the reduction already achieved between 1990 and 2008 (Olivier et al., 2015). However, this might not always be the case on national and local scales, or for a given emitting sector, according to the trends in GHG emissions since 1990 (Kona et al., 2016). 
Figure 4 shows information about final energy consumptions per capita, per municipality at BEI year. This energy index is expressed per population in order to easily compare the different municipalities (municipalities in white are the ones without data in the SEAP).

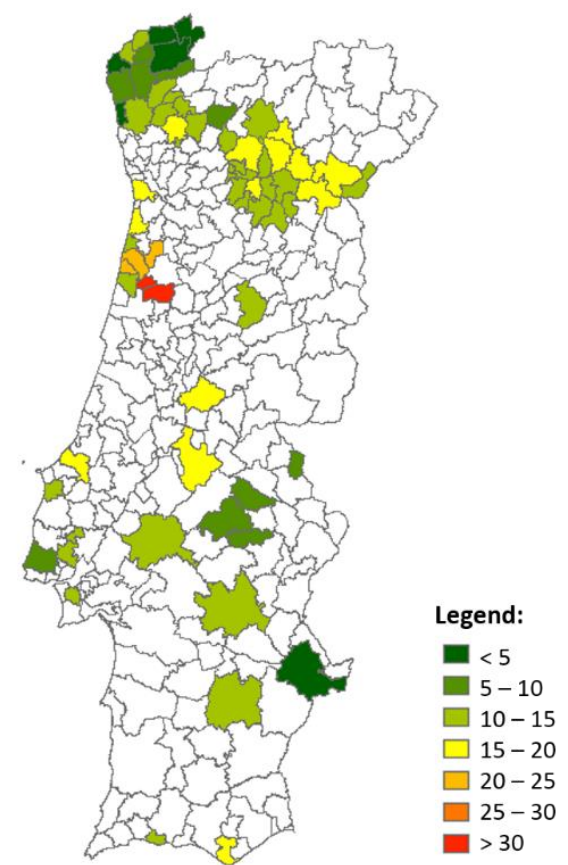

Figure 4. Energy consumption per capita, in MWh/year, per municipality, at BEI year.

The order of magnitude between the energy consumption ratios found is in some cases 6 times higher than others. There is no spatial homogeneous distribution of this energy consumption: the highest consumption per capita is found in Oliveira do Bairro and Anadia, while the lowest are found in municipalities located in the northern and eastern border.

Regarding the type of emission reduction measures that integrate the SEAP, in general, they cover different sectors of activity and different emission sources. The main sectors of activity considered in the SEAP are municipal and non-municipal services, housing, industry, transport and agriculture, forestry and fisheries.

All measures were analysed according to the potential for reducing emissions in each municipality, based on their specific characteristics and the identification of sources of $\mathrm{CO}_{2}$ emissions resulting from the BEI. The national and regional strategic objectives with an impact on energy sustainability were also considered.

In most cases (64\%), the implementation of the proposed measures cover the period from 2009 to 2020, corresponding to the period after the reference year (year 2008), until the year of verification of compliance with the targets proposed (year 2020).

The measures considered in this SEAP were divided into behavioural and infrastructural measures, as shown in Table 1. 
Table 1. Emission reduction measures included in the SEAP.

\begin{tabular}{|c|c|c|c|c|c|}
\hline \multirow{2}{*}{\multicolumn{2}{|c|}{$\begin{array}{l}\text { Sector } \\
\text { Behavioural }\end{array}$}} & \multicolumn{4}{|l|}{ Measures } \\
\hline & & B1. Creating support office & $\begin{array}{l}\text { B2. D } \\
\text { Econ }\end{array}$ & $\begin{array}{l}\text { nition of } \\
\text { ic Incentives }\end{array}$ & $\begin{array}{l}\text { B3. Awareness in } \\
\text { sustainability }\end{array}$ \\
\hline \multirow[t]{5}{*}{ Structural } & Energy & \multicolumn{2}{|l|}{ E4. Using renewable energies } & \multicolumn{2}{|c|}{ E5. Improving energy efficiency in buildings } \\
\hline & & \multicolumn{2}{|c|}{ E6. Optimization of public lighting } & \multicolumn{2}{|c|}{$\begin{array}{l}\text { E7. Improvements in air conditioning and } \\
\text { ventilation systems }\end{array}$} \\
\hline & & \multicolumn{2}{|c|}{$\begin{array}{l}\text { E8. Improving the efficiency of } \\
\text { small electrical equipment }\end{array}$} & \multicolumn{2}{|c|}{$\begin{array}{l}\text { E9. Improved efficiency of industrial processes and } \\
\text { equipment }\end{array}$} \\
\hline & Waste & \multicolumn{4}{|c|}{ W10. Optimization of waste management } \\
\hline & Transport & $\begin{array}{l}\text { T11. Optimization of } \\
\text { transport infrastructures }\end{array}$ & \multicolumn{2}{|c|}{$\begin{array}{l}\text { T12. Optimization of used } \\
\text { vehicles }\end{array}$} & $\begin{array}{l}\text { 13. Optimization of road } \\
\text { perations }\end{array}$ \\
\hline
\end{tabular}

Behavioural measures include all measures that depend on behavioural changes and will thus help speed up the dissemination of other measures. From the analysis of the 70 SEAP, 3 main behavioural measures were found:

- Creating support office (B1): promote and create a technical framework for energy efficiency advice for the industry and services sector (present in only $30 \%$ of the SEAP analysed - see Figure 5);

- Definition of economic incentives (B2): technical support and positive discrimination to new sustainable and certified real estate investments;

- Awareness in sustainability (B3): plan a set of actions to raise awareness and educate the population for environmental and energy practices; and promote and create technical structures for energy efficiency advice, focusing on condominiums and/or neighbourhood organizations.

These measures are easy to implement and it is always positive when citizens can actively participate, with added motivation and security due to technical support. A possible challenge of these measures would be social acceptance, many citizens might remain unaware of sustainability actions due to lack of interest.

Infrastructure measures include all measures that depend on changes in infrastructures, equipment or production and management processes, mostly divided in the areas of energy, transport and waste. From the analysis of the 70 SEAP, 10 main infrastructure measures were found, where 6 of them are related to energy, 1 to waste and 3 to transport.

Energy measures are the most consensual in all SEAPs analysed, and some of these measures are mentioned by all municipalities (see Figure 5). The energy measures are: 
- Using renewable energies (E4): install solar thermal collectors in domestic buildings, human health activities, sports activities, etc.; promotion of the use of forest biomass and forest residues as fuel for the sustainable production of various forms of final energy; promotion of biofuels use as the main fuel or in mixtures with other fuels; promotion and incentive to invest in microgeneration projects and other projects of energy production for self-consumption or selling energy using renewable energy sources.

- Improving energy efficiency in buildings (E5): conduct audits in buildings, utilities and industries to assess the degree of energy efficiency they are in and identify the potential for improvement.

- Optimization of public lighting (E6): elaboration of an efficient lighting plan that includes the participation of energy managers in services, public equipment and/or private agents; the replacement of inefficient luminaires by more efficient ones, to improve the quality/cost ratio.

- Improvements in air conditioning and ventilation systems (E7): improve the energy efficiency of air conditioning and ventilation systems in tourist accommodation, services, domestic, human health activities and sports and recreational activities, among others.

- Improving the efficiency of small electrical equipment (E8): promote a gradual renovation of household appliances inefficient energy consumers, especially home appliances; promote the gradual renewal of energy-efficient office equipment, by more efficient ones.

- Improved efficiency of industrial processes and equipment (E9): improve the gradual renewal of industrial equipment by more efficient ones and optimize industrial processes to improve the sector's climate sustainability.

On the one hand, the largest advantage of these measures is taking a step towards a sustainable future. In addition, Portugal is one of the countries with the largest solar exposure in the EU, which easily allows solar solutions for renewable energy. On the other hand, there is always a cost associated with each measure, which greatly varies depending on the building or process that is the target for energy efficiency or renewable energy use. The implementation of these measures needs to be carefully studied on a case-by-case scenario.

The only waste measure relates to "Optimization of waste management" (W10), and aims to improve the waste management model, achieving the maximum efficiency of energy use. This measure is present in $73 \%$ of the analysed plans (Figure 5).

Transport measures, such as energy measures, are identified as being very important, being present in at least $70 \%$ of SEAPs (see Figure 5). Transport measures are:

- Optimization of transport infrastructures (T11): study and create new routes for the permanent and/or temporary transport network, with more and better interconnections 
- Timers adjustment;

- More efficient lamps;

- Turn off unnecessary lighting.

\section{SEAP ANALYSIS: FOCUS ON PUBLIC LIGHTNING}

Public Lightning is an important part of municipality's night-time landscape. Lighting can be used to enhance public safety and security while improving the aesthetic appeal of the surrounding properties but with the current global financial crisis, such lighting systems must also be sustainable.

Almost all of these measures are simple to implement and can be highly profitable in terms of energy reduction and associated costs for the municipal authorities.

To review the state of public lighting in the SEAP plans for Portugal, data was gathered from the Covenant of Mayors (including (i) public lighting consumptions per year; (ii) percentage of public lighting consumption in total electricity consumptions; (iii) measures to reduce public lighting consumptions) and also from the PORDATA database (http://www.pordata.pt). The SEAP data consists of public lighting energy consumption per year and what percentage of total energy demand it represents. As for the PORDATA data, the main values obtained are in regards to municipal revenues, population and area. The 70 municipalities in Portugal with detail SEAP were the focus of this analysis.

Figure 6 shows the total public lighting energy consumption and percentage of public lighting consumption relative to the total energy consumption of that municipality.

Figure 6. Public lighting consumptions per year (MWh) (a) and percentage of lighting

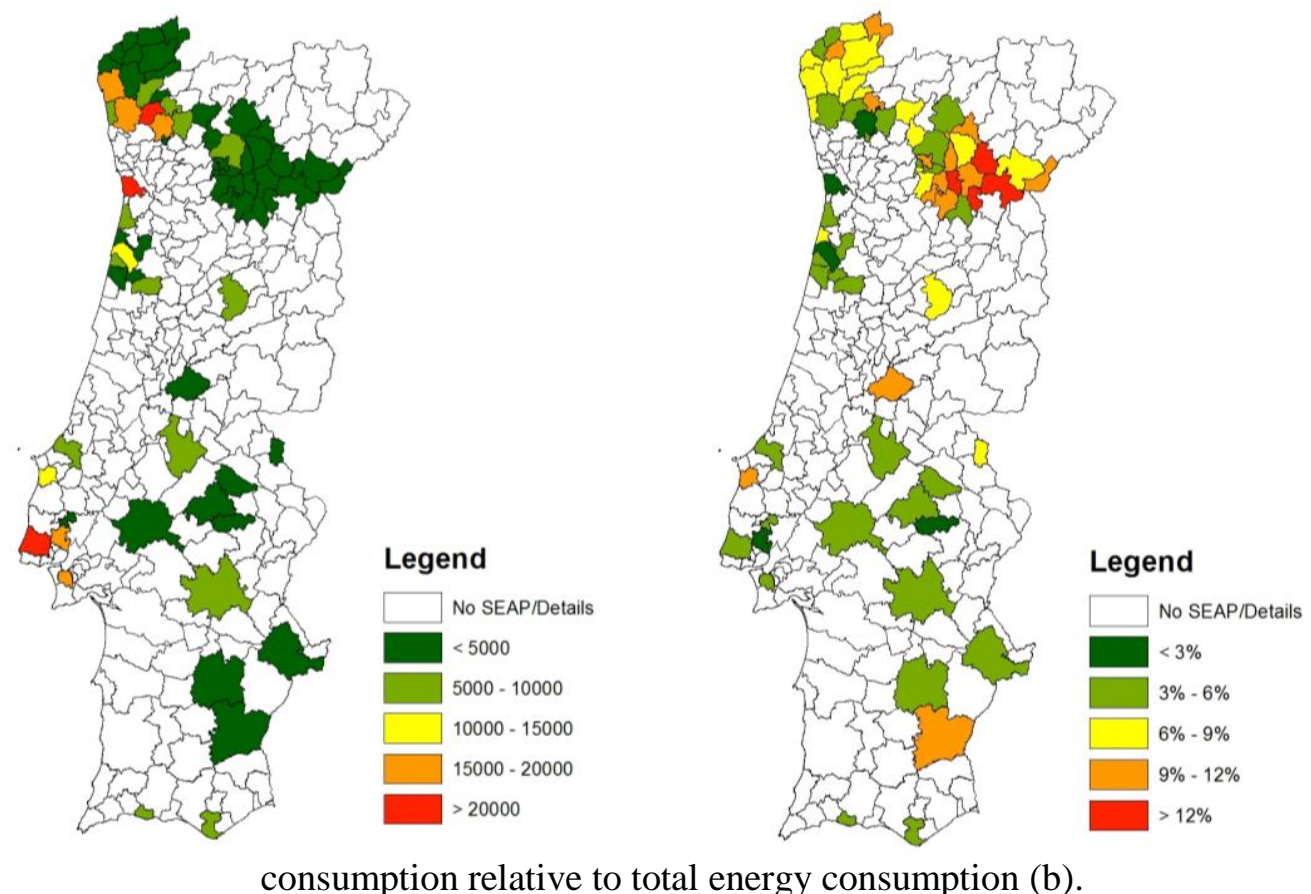


Public lighting plays a key role in energy consumption, reaching values of upwards of $12 \%$, which represents a considerable amount of energy and cost to the municipality, which is a significant part with potential to be reduced. It is curious to notice that the municipalities where public lighting have higher relative consume (more than $10 \%$ regarding the total energy consumption) are located in the interior north region of Portugal, with lower urban density and more rural characteristics.

In order to better interpret these results, a more detailed analysis is performed by comparing the energy consumption of the municipalities taking into account their population, total area and revenue (see Figure 7).

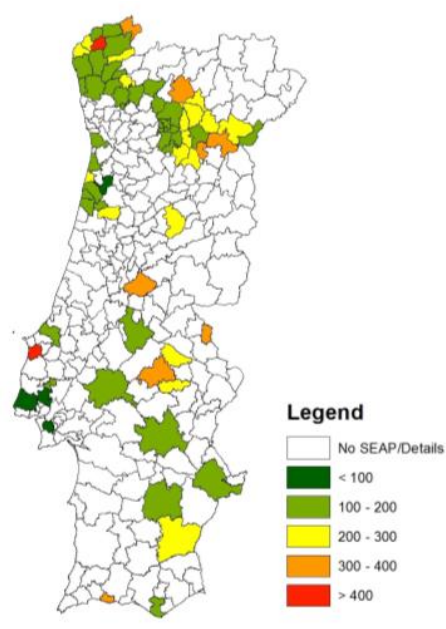

(a)

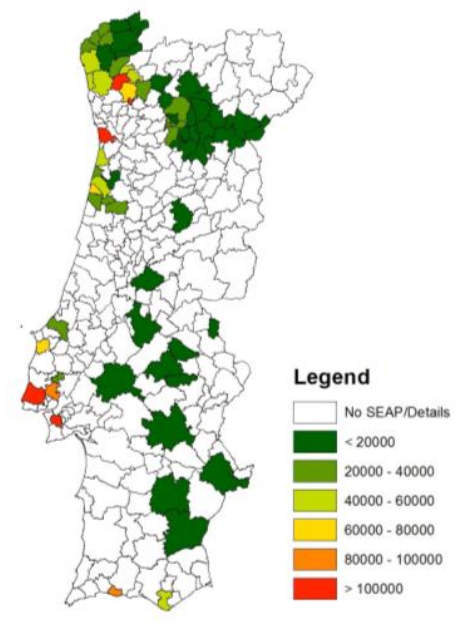

(b)

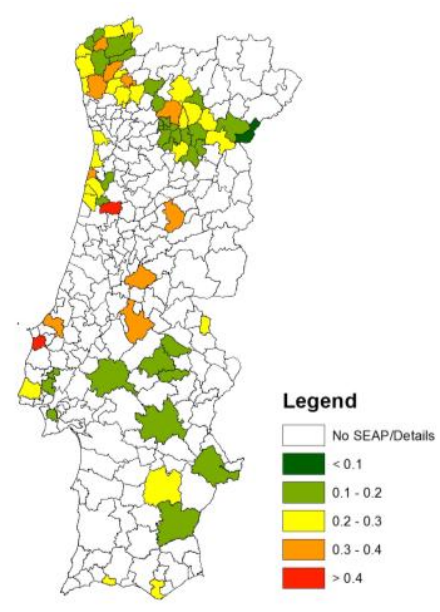

(c)

Figure 7. Public lighting energy consumption (kWh/year) per (a) capita, (b) area $\left(\mathrm{km}^{2}\right)$ and (c) municipal revenue (€/year).

Regarding the consumption of public lighting energy per capita, there are a wide range of values, with no clear geographical distribution. The municipalities located in the interior north (and some of them also in central and southern regions) already highlighted in terms of relative absolute consumption (Figure 6) exhibit large consumption per capita, which is justified by the low population density of these municipalities. Nevertheless, the analysis of the energy consumption per area reveals higher values near the coast, explained by the higher population density and urban residential areas. In the municipalities located in the interior, the consumption per area is mostly below $2000 \mathrm{kWh} / \mathrm{km}^{2}$ per year, while the main urban municipalities higher than $100000 \mathrm{kWh} / \mathrm{km}^{2}$ per year. These results show how important it is to make a relative analysis of the energy consumption, and how it depends on the variables considered.

Regarding the consumption of public lighting energy per revenue, there are municipalities with the ratio between consumption and municipal revenues 3 times higher than others. The 
municipalities with the most revenue are also the ones with the highest amount of population and energy consumption.

In order to complement this spatial analysis, a correlation study was made between the public lighting energy consumption and the three variables considered (area; population and municipalities revenues) - see Figure 8.

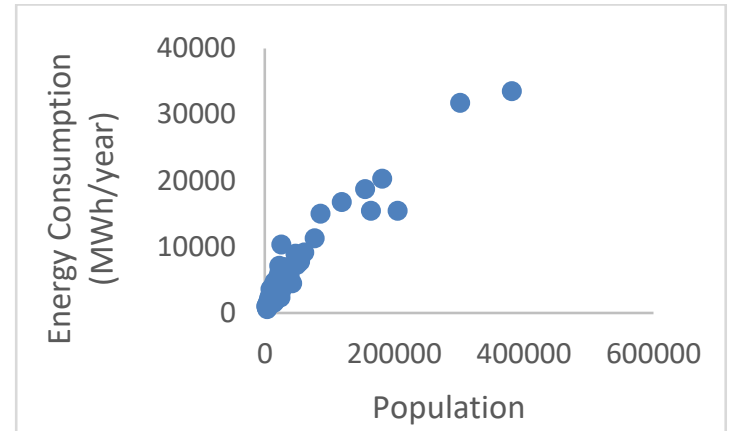

(a)

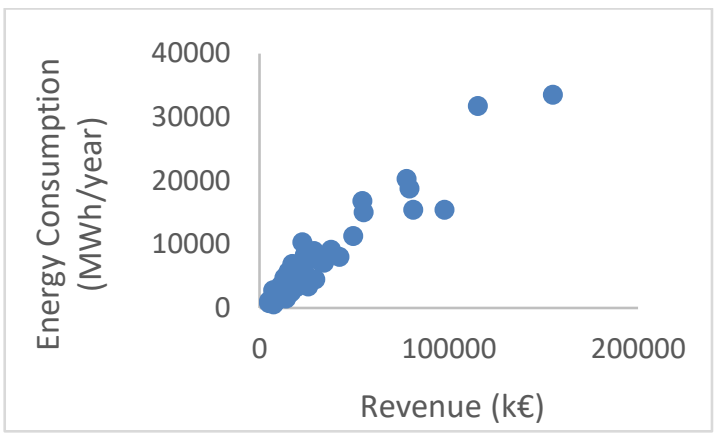

(b)

Figure 8. Correlation between energy consumption and (a) population and (b) municipality revenue.

No correlation was found between the area and energy consumption for public lighting (not shown), but there is a correlation (close to linear) between the amount of public lighting energy spent and the resident population and also the municipality revenue.

\section{CONCLUSIONS}

The adoption of the Covenant of Mayors by Portuguese municipalities was explored in this work, where it is found that around $30 \%$ have signed it. However, these represent approximately $60 \%$ of the total population of the country because the main urban centres are a part of the $30 \%$ that have signed the CoM. The majority of the assignments assume the minimum goal of $20 \%$ reduction, with the exception of more ambitious municipalities.

The measures included in the SEAPs comprehend behavioural measures, which include all measures that depend on behavioural changes and will thus help speed up the dissemination of other measures, infrastructure measures and equipment or production and management processes, mostly divided in the areas of energy, transport and waste. From the analysis of the 70 SEAP, 3 main behavioural measures were found (namely creating a support office; definition of economic incentives and awareness in sustainability) and 10 main infrastructure measures (6 related to energy, 1 to waste and 3 to transport).

The energy measures comprehend the use of renewable energies, improving energy efficiency in buildings; optimization of public lighting; improvements in air conditioning and ventilation systems; improving the efficiency of small electrical equipment and improved efficiency of industrial processes and equipment. Transport measures are also identified as being very 
important, being present in at least $70 \%$ of SEAPs, which includes optimization of transport infrastructures; optimization of used vehicles and optimization of road operations.

Public lighting is one of the energy measures present in all submitted SEAP, which plays a key role in energy consumption, reaching values of upwards of $12 \%$. The analysis of the energy consumed in public lighting per area reveals higher values near the coast ( 2 orders of magnitude greater), explained by the higher population density and urban residential areas. It is important that the CoM will increase the local authorities awareness, especially to public lighting. Portuguese municipalities are starting to pay more attention to energy efficiency measures and starting to educate their citizens. Although challenging, and with the country going through an economic crisis for the past decade, Portugal has been increasing the renewable share of energy production and overall energy production has stabilized. In the future, new measures will be easier to implement because the country is already on a sustainable path.

\section{ACKNOWLEDGEMENTS}

Thanks are due for the financial support to FCT/MEC through national funds, and the co-funding by the FEDER, within the PT2020 Partnership Agreement and Compete 2020, for the AIRSHIP project (PTDC/AAG-MAA/2569/2014 - POCI-01-0145-FEDER-016752).

\section{REFERENCES}

Amorim E.V., 2014. Sustainable energy action plans: project management intercomparison. Procedia Technol., 16, pp.4-13.

Bertoldi P., Cayuela D.B., Monni S., de Raveschoot R.P. 2010. How to develop a Sustainable Energy Action Plan (SEAP) - Guidebook. EUR 24360. Luxembourg: Publication Office of the European Union.

Bjelic I.B., Ciric R.M., 2014. Optimal distributed generation planning at a local level - A review of Serbian renewable energy development. Renew. Sustain. Energy Rev., 39, pp.79-86.

Castán V., Bulkeley, H., 2012. A survey of urban climate change experiments in 100 cities Global Environ Change, 23 (1), 92-102.

Cerutti A.K., Iancu A., Janssens-Maenhout G., Melica G., Paina F., Bertoldi P., 2013. The Covenant of Mayors in Figures: 5-Year Assessment. JRC Science and Policy Reports, European Commission. Publications Office of the European Union, Luxemburg.

Christoforidis G.C., Chatzisavvas K.C., Lazarou S., Parisses C., 2013. Covenant of Mayors initiative - Public perception issues and barriers in Greece. Energy Policy, 60, pp.643-655.

Croci, E., Lucchitta, B., Janssens-Maenhout, G., Martelli, S., Molteni, T., 2017. Urban CO2 mitigation strategies under the Covenant of Mayors: An assessment of 124 European cities. Journal of Cleaner Production (in press). 
Dall'O G., Galante A., Pasetti G., 2012. A methodology for evaluating the potential energy savings of retrofitting residential building stocks. Sustain. Cities Soc., 4, pp.12-21.

Dall'O G., Norese M.F., Galante A., Novello C., 2013. A multi-criteria methodology to support public administration decision making concerning sustainable energy action plans. Energies, 6 (8), pp.4308-4330.

Dams $\varnothing$ T., Kjær T., Christensen T.B., 2016. Local climate action plans in climate change mitigation - Examining the case of Denmark. Energy Policy, 89, pp.74-83.

Delponte I., Pittaluga I., Schenone C., 2017. Monitoring and evaluation of Sustainable Energy Action Plan: Practice and perspective. Energy Policy, 100, pp.9-17.

Doukas H., Papadopoulou A., Savvakis N., Tsoutsos T., Psarras J., 2012. Assessing energy sustainability of rural communities using Principal Component Analysis. Renew. Sustain. Energy Rev., 16 (4), pp.1949-1957.

EC, 2014. Reporting Guidelines on Sustainable Energy Action Plan and Monitoring. Covenant of Mayors \& Joint Research Centre of the European Commission.

EC. 2017. Covenant of Mayors - The Covenant of Mayors. Available at: http://www.covenantofmayors.eu/about/covenant-of-mayors_en.html

Famoso F., Lanzafame R., Monforte P., Scandura P.F., 2015. Analysis of the Covenant of Mayors Initiative in Sicily. Energy Procedia, 81, pp.482-492.

Heidrich O., Dawson R.J., Reckien D., Walsh C.L., 2013. Assessment of the climate preparedness of 30 urban areas in the UK. Clim.Change, 120 (4), pp.771-784.

Helm D., 2014. The European framework for energy and climate policies. Energy Policy, 64, pp.29-35.

Hoff J., Strobel B.W., 2013. A municipal 'climate revolution'? the shaping of municipal climate change policies. J. Transdiscipl. Environ. Stud., 12 (1), pp.3-14

Iancu A., Martelli S., Cerutti A.K., Janssens-Maenhout G., Melica G., Rivas-Calvete S., Kona A., Zancanella P., Bertoldi P., 2015. A harmonised dataset of greenhouse gas emissions inventories from cities under the EU Covenant of Mayors initiative. Earth Syst. Sci. Data Discuss., 8, pp.461507.

Kern K., Bulkeley H., 2009. Cities, Europeanization and multi-level governance: governing climate change through transnational municipal Networks. J Common Market Stud, 47 (2), pp.309-332.

Kona A., Melica G., Koffi B., Iancu A., Zancanella P., Rivas Calvete S., Bertoldi P., Janssens Maenhout G., Monforti-Ferrario F., 2016. Covenant of Mayors: Greenhouse Gas Emissions Achievement and Projections. EUR 28155 EN. Luxembourg: Publications Office of the European Union.

Kona A., Melica G., Rivas S., Zancanella P., Iancu A., Gabrielaitiene I., Saheb Y., Janssens-Manhout G., Bertoldi P., 2015. The Covenant of Mayors in Figures and Performance 
Indicators: 6-Year Assessment. JRC Science and Policy Reports, European Commission, Publications Office of the European Union, Luxembourg.

Krause R.M., 2011. Policy innovation, intergovernmental relations, and the adoption of climate protection initiatives by U.S. cities. J Urban Affairs, 33 (1), pp.45-60.

Kyriakarakos G., Patlitzianas K., Damasiotis M., Papastefanakis D., 2014. A fuzzy cognitive maps decision support system for renewables local planning. Renew. Sustain. Energy Rev., 39, pp.209-222.

Lombardi M., Rana R., Pazienza P., Tricase C., 2014. The European policy for the sustainability of urban areas and the "Covenant of Mayors" initiative: a case study. In: Salomone R., Saija G. (Eds.), Pathways to Environmental Sustainability. Springer International Publishing, Cham, pp.183-192.

Magni F., Maragno D., 2014. Sustainable Energy Action Plans (SEAP) and the Climate Plans: New tools for local environmental planning. In: ECTP-CEU (Ed.), Spatial Planning \& Energy Young Planners Workshop. European Council of Spatial Planners and Conseil Européen des Urbanistes, Brussels, pp.33-54.

Marinakis V., Papadopoulou A.G., Doukas H. and Psarras J., 2015. A web tool for sustainable energy communities. Int. J. Information and Decision Sciences, 7 (1), pp.18-31.

Marinakis V., Papadopoulou A.G., Psarras J., 2017. Local communities towards a sustainable energy future: Needs and priorities. Int. J. Sustain. Energy, 36 (3), pp.296-312.

Marinakis V., Xidonas P. and Doukas H., 2016. A modelling framework for the forecasting of energy consumption and $\mathrm{CO} 2$ emissions at local/regional level, Int. J. Global Energy Issues, 39 (6), pp.444-460.

Matak N. Krajačić G., Pilato A.M., 2016. Integrating sustainable energy action plans for island municipalities - case study of Korcula. Thermal Science, 20 (4), pp.1037-1048

Melica G., Bertoldi P., Kona A., Rivas S., Zancanella P., Janssens-Maenhout G., Cerutti A.K., Iancu A., Ganisheva K., 2014. The Covenant of Mayor initiative: An Assessment and Evaluation. ACEEE Summer Study on Energy Efficiency in Buildings. American Council for an EnergyEfficient Economy, Washington D.C.

Nuss-Girona S., Llausàs A., Figueras J., Morera S., 2016. The SEAP in the city of Girona, a crossroads between boldness and pragmatism. Local Environment, 21 (4), pp.476-503

Oliver-Solà J., Armero M., De Foix B.M., Rieradevall J., 2013. Energy and environmental evaluation of municipal facilities: case study in the province of Barcelona. Energy Policy, 61, pp.920-930.

Olivier J., Janssens-Maenhout G., Muntean M., Peters J. 2015. Trends in global CO2 emissions; 2015 Report, The Hague: PBL Netherlands Environmental Assessment Agency; Ispra: European Commission, Joint Research Centre. 
Pablo-Romero M.P., Pozo-Barajas R., Sánchez-Braza A., 2015a. Understanding local $\mathrm{CO}_{2}$ emissions reduction targets. Renew. Sustain. Energy Rev., 48, pp.347-355.

Pablo-Romero M.P., Pozo-Barajas R., Sánchez-Braza A., 2016. Analyzing the effects of Energy Action Plans on electricity consumption in Covenant of Mayors signatory municipalities in Andalusia. Energy Policy, 99, pp.12-26

Pablo-Romero M.P., Sánchez-Braza A., González-Limón J.M., 2015b. Covenant of Mayors: reasons for being an environmentally and energy friendly municipality. Rev. Policy Res., 32 (5), pp.576-599.

PORDATA, 2015. Consumo de energia eléctrica por tipo de consumo. Available at: http://www.pordata.pt/DB/Portugal.

Radulovic. D., Skok S., Kirincic V., 2011. Energy efficiency public lighting management in the cities. Energy, 36 (4), pp.1908-1915.

Reckien D., Flacke J., Dawson R.J., Heidrich O., Olazabal M., Foley A., et al., 2014. Climate change response in Europe: What's the reality? Analysis of adaptation and mitigation plans from 200 urban areas in 11 countries. Clim Change, 122 (1-2), pp.331-340.

Rivas S., Melica G., Kona A., Zancanella P., Serrenho T., Iancu A., Koffi B., Gabrielaitiene I., Janssens-Maenhout G., Bertoldi P., 2015. The Covenant of Mayors: In-depth Analysis of Sustainable Energy Actions Plans. JRC Science and Policy Reports, European Commission, Publications Office of the European Union, Luxembourg.

Romero-Lankao P., 2012. Governing carbon and climate in the cities: an overview of policy and planning challenges and options. Eur Plann Stud, 20 (1), pp.7-26

Sharp E.B., Daley D.M., Lynch M.S., 2011. Understanding local adoption and implementation of climate change mitigation policy. Urban Affairs Rev, 47 (3), pp.433-457.

Wang R., 2012. Leaders, followers, and laggards: adoption of the US conference of Mayors climate protection agreement in California. Environ Plann C, 30 (6), pp.1116-1128.

Yalçın M., Lefèvre B., 2012. Local climate action plans in France: emergence, limitations and conditions for success. Environ Policy Governance, 22 (2), pp.104-115.

Zahran S., Grover H., Brody S.D., Vedlitz, A., 2008. Risk, stress, and capacity. Explaining metropolitan commitment to climate protection. Urban Affairs Rev, 43 (4), pp.447-474.

Zanni D., Righi A., Mora T.D., Peron F., Romagnoni P., 2015. The Energy improvement of school buildings: analysis and proposals for action. Energy Proc., 82, pp.526-532 